\title{
Preoperative and Postoperative Spirometry in Patients Undergoing Lobectomy for Sequelae of Pulmonary Tuberculosis
}

\author{
Elias Amorim ${ }^{1}$, Roberto Saad Jr. ${ }^{2}$, Armando Veiga Da Cruz Filho ${ }^{3}$ \\ ${ }^{1}$ Thoracic Surgery Service of the Hospital, Universitário da UFMA, São Luis, Brazil; ${ }^{2}$ The Discipline of Thoracic Surgery, Depart- \\ ment of Surgery, The School of Medical Sciences, The Santa Casa de São Paulo Hospital, São Luis, Brazil; ${ }^{3}$ The Hospital Municipal \\ de São Luis, São Luis, Brazil. \\ Email: amorimelm@gmail.com
}

Received December $7^{\text {th }}$, 2012; revised January $15^{\text {th }}$, 2013; accepted January $30^{\text {th }}, 2013$

Copyright (c) 2013 Elias Amorim et al. This is an open access article distributed under the Creative Commons Attribution License, which permits unrestricted use, distribution, and reproduction in any medium, provided the original work is properly cited.

\begin{abstract}
Objective: To assess preoperative and postoperative spirometry values in patients undergoing lobectomy for sequelae of pulmonary tuberculosis. Method: A total of 20 patients (10 males) with history of treatment for tuberculosis and presenting with symptomatic sequelae (repeat infection or hemoptysis) who sought assistance at the chest surgery outpatient clinic between 11.09 .07 and 04.02 .10 , were selected for the study. Only patients that met theeligibility criteria (symptomatic, submitted to tuberculosis treatment) were included in the study. The age of patients ranged from 15 to 56 years (mean: 35.75 years). The average treatment time for tuberculosis was 6 months and onset of symptoms occurred between 01 and 32 years after treatment. To assess the impact of surgery on the variables VC, FVC, FEV $1, \mathrm{FEV}_{1} / \mathrm{FVC}$, FEF and PEF preoperative values were compared with postoperative values at $1^{\text {st }}, 3^{\text {rd }}, 6^{\text {th }}$ and $12^{\text {th }}$ month using the paired t test. The level of significance $(\alpha)$ applied for all tests was $5 \%$ where a value of $\mathrm{p}<0.05$ was considered significant. Results: 11 patients were treated because of recurrent infections and 9 because of haemoptysis. The most common lobectomy was right upper lobectomy (7 patients), followed by left upper lobectomy (6 patients), left lower lobectomy (6 patients), and right middle lobectomy (1 patient). There were no postoperative complications. There was no postoperative mortality. Conclusion: Based on the results of the present study, it can be concluded that, at the $12^{\text {th }}$ postoperative month, spirometric parameters of patients with tuberculosis sequelae submitted to lobectomy had returned to preoperative levels.
\end{abstract}

Keywords: Lobectomy; Tuberculosis; Spirometry; Preoperative Care; Postoperative Care

\section{Introduction}

Tuberculosis (TB) remains common in some countries including Brazil [1]. TB continues into the $21^{\text {st }}$ century as an unresolved public health problem representing an important cause of morbi-mortality [2]. It is the most common infectious disease in humans [3] and the cause of death in around 3 million people worldwide annually, being the third most prevalent infectious disease but having the highest death rate [4]. TB is perhaps the oldest disease known to man, with records of lesions found in the vertebrae of Egyptian mummies dating back almost four thousand years [5-8].

Currently, TB is placed in a unique epidemiological

*Study conducted at the Hospital Universitário of the Federal University of Maranhão, Presidente Dutra Unit. and socioeconomic context characterized by a global demographic transition which has led to a marked aging of the population [1,9].

Diagnosis of disease activity in patients with pulmonary tuberculosis (PTB) is based on multiple factors such as clinical status, physical exam, tuberculin test and mainly on the detection of the bacillus in sputum, bronchialveolar lavage, transtracheal aspirate or lung tissue biopsy samples. These factors are supported by others such as sequential changes on chest radiographs and previous history of anti-tuberculosis therapy $[1,10]$.

With the advent of modern chemotherapy, a dramatic reduction in tuberculosis ensued, commencing with the discovery of streptomycin in 1944 and the anti-tuberculosis activity of isoniazid in 1952 [11,12].

The most frequent sequelae of tuberculosis are lung 
damage, bronchiectasis, fungal ball, tracheal stenosis in addition to other less common sequelae [13].

The pulmonary function test, ventilatory test or spirometry, is extremely important for indications of surgical treatment because it is used to assess whether the patient can tolerate anesthesia and if morbimortality is increased. [14]

Specifically for tuberculosis, a frequently occurring disease in Brazil, particularly in Maranhão state, few references are available in the literature of studies investigating alterations in lung function after resection of the parenchyma [15].

The School of Medical Sciences of the Santa Casa de São Paulo Hospital (FCMSCSP), among their research lines, is currently conducting studies involving the assessment of preoperative and postoperative pulmonary function tests. Many of these studies have been concluded [16-19].

Against this background, and providing continuity to the line of research pursued by the institution, we sought to assess preoperative and postoperative spirometry values in patients undergoing lobectomy for sequelae of previously treated pulmonary tuberculosis. This is the first study of this nature ever undertaken in our medical setting.

\section{Method}

The study was approved by the Research Ethics Committee of the Hospital Universitário Unidade Presidente Dutra-HUUFMA.

A total of 20 patients (10 males) with history of treatment for tuberculosis and presenting with symptomatic sequelae i.e. repeat infection or hemoptysis, who sought the chest surgery outpatient clinic of the Hospital Universitário Presidente Dutra of the Federal University of Maranhão between 11.09.07 and 04.02.10, were selected for the study.

In the sample studied, patient age ranged from 15 to 56 years (mean $=3575$ years), the treatment time for tuberculosis was 06 months and onset of symptoms occurred between 01 and 32 (mean $=7.8$ years) years after treatment.

After clinical interview with reporting of recurrent hemoptysis and previous history of treated tuberculosis, chest radiograph and CT exams were ordered.

With radiologically-confirmed diagnosis of sequelae, pre-operative exams were requested: perfusion scintigraphy and pulmonary ventilation, sputum stain test for acidfast bacilli, blood analyses, cardiologic assessment and pulmonary function tests (PFT).

\section{Pulmonary Function Tests}

The volume-time curve obtained by forced spirometry was performed according to the criteria standardized in 1995 by the American Thoracic Society (ATS) [20], with the best of three acceptable curves chosen. Forced vital capacity (FVC), forced expiratory volume in one second (FEV1), forced expiratory flow (FEF) between 25\% $75 \%$, FEV1/FVC ratio, and peak expiratory flow (PEF) values were derived from the best curve. The normative reference values proposed by Pereira $e t$ al. in 2001 were used for all curves [21].

The comparison of impact of surgery on the variables (VC, FVC, $\mathrm{FEV}_{1}, \mathrm{FEV}_{1} / \mathrm{FVC}, \mathrm{FEF}$ and PEF) at the $1^{\text {st }}$, $3^{\text {rd }}, 6^{\text {th }}$ and $12^{\text {th }}$ month post-operatively versus preoperatively, was performed using the paired $t$ test. The level of significance (a) applied for all tests was $5 \%$, i.e. was deemed significant at $\mathrm{p}<0.05$.

\section{Results}

\subsection{Interventions}

11 patients were treated because of recurrent infections and 9 because of haemoptysis. The most common lobectomy was right upper lobectomy (7 patients), followed by left upper lobectomy (6 patients), left lower lobectomy (6 patients), and right middle lobectomy (1 patient). Therewere no postoperativecomplications. There was no postoperative mortality.

\subsection{Vital Capacity}

The mean VC value significantly decreased post-operatively from $2.83 \mathrm{~L}$ preoperatively to $2.12 \mathrm{~L}$ at the first postoperative month. It progressively increased to $2.43 \mathrm{~L}$ six months postoperatively, but differences still remained statistically significant compared with preoperative values (Figure 1).

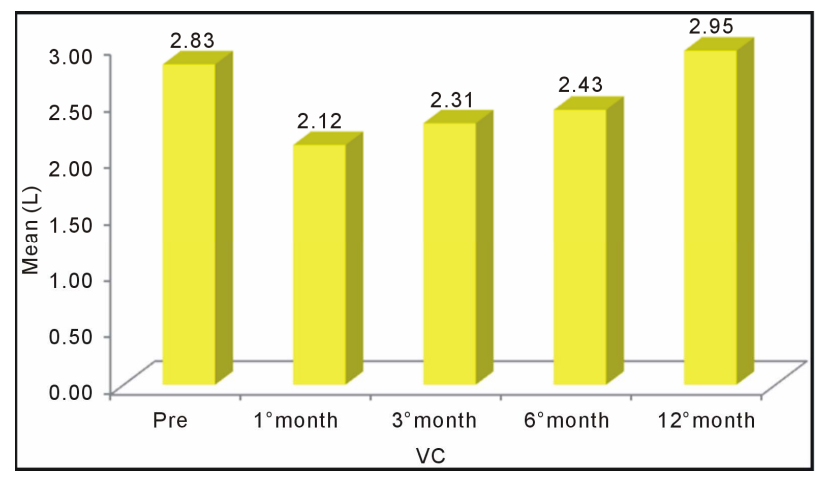

Figure 1. Mean vital capacity (VC) values with standard deviations and calculated " $p$ " values for comparison of preoperative and postoperative periods. A significant difference $(p<0.05)$ was observed in the means of the preoperative and postoperative periods for all three comparisons (preoperative and first month, preoperative and third month, preoperative and sixth month). 


\subsection{Forced Vital Capacity}

As with VC, the mean FVC value also decreased one month after resection to progressively increase thereafter. However, at the sixth postoperative month, it still was significantly lower than the preoperative value (Figure 2).

\subsection{Forces Expiratory Volume in One Second}

The comparison of the mean values of FEV1 showed no statistically significant differences between the preoperative value and the value at six months postoperatively. However, there were statistically significant differences when the preoperative value was compared with those at the first and third postoperative months. In this case, a progressive recovery was observed during the first six months after lobectomy (Figure 3).

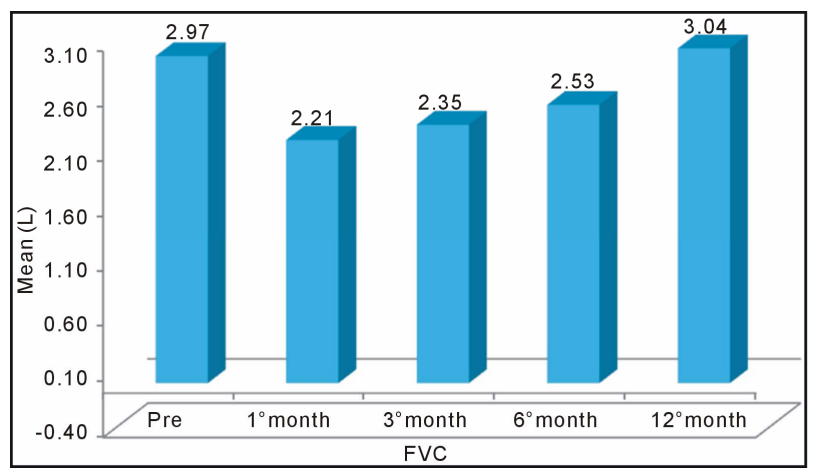

Figure 2. Mean forced vital capacity (FVC) values at the four timepoints: One preoperative and three postoperative. A statistically significant difference was found on comparison of the four timepoints $(p<0.05)$.

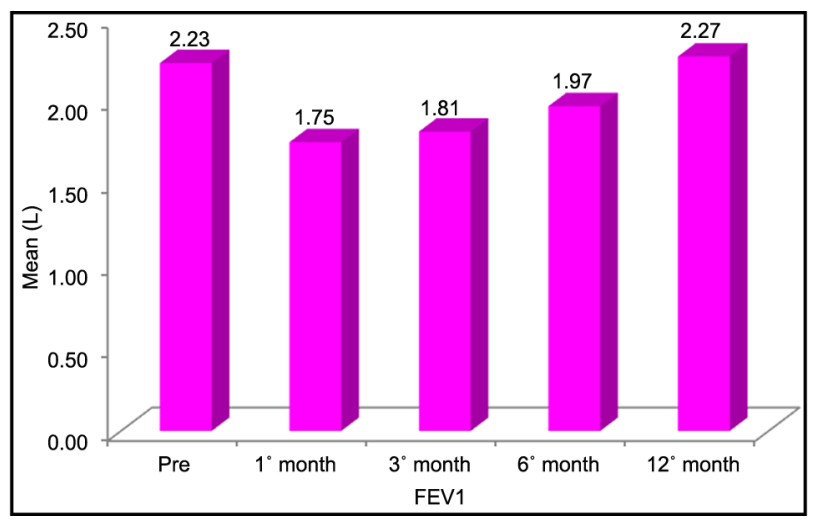

Figure 3. Mean forced expiratory volume in one minute (FEV1) values of the four timepoints: one preoperative and three postoperative. No statistically significant difference (p $>0.05$ ) was found between the preoperative value and that at sixth months postoperatively, but a significant difference $(p<0.05)$ was evident for the other two comparisons (preoperative versus first month and preoperative versus third month). A progressive recovery of values was observed.

\subsection{Peak Expiratory Flow}

A significant decrease in PEF was observed across the postoperative period, with no significant recovery at six months postoperatively (Figure 4).

\subsection{Forces Expiratory Volume in One Second/Forced Vital Capacity}

Figure 5 depicts the mean values of FEV1/FVC of fourstages: pre-and postoperatively. There was nostatistically significant differences ( $p>0.05$ ) when compared with preoperative values. For this test, full recovery occurred six months after resection.

\subsection{Forced Expiratory Flow}

Figure 6 shows the mean values of FEF in four periods: pre- and postoperative. There was nostatistically significant difference $(p>0.05)$ among all comparisons with the initial FEF.

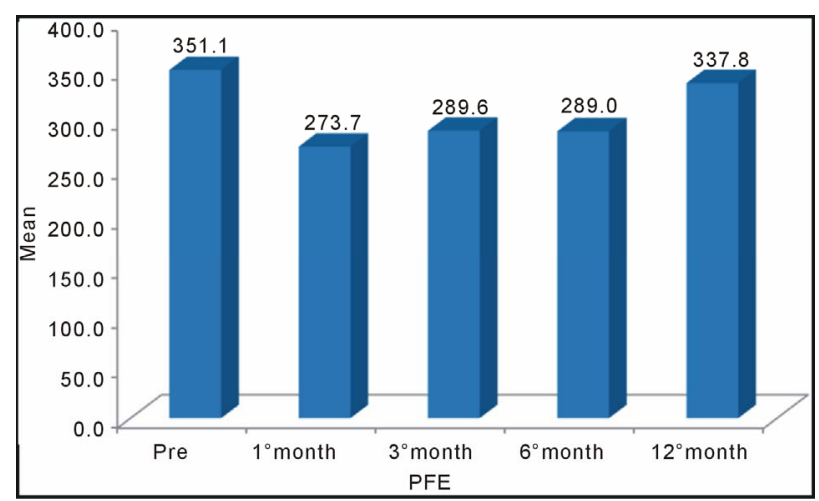

Figure 4. Mean PEF values of the four timepoints: one preoperative and three postoperative. A statistically significant difference $(p<0.05)$ was evident on all comparisons with initial PEF, indicating that full recovery of the PEF had not occurred by the sixth month.

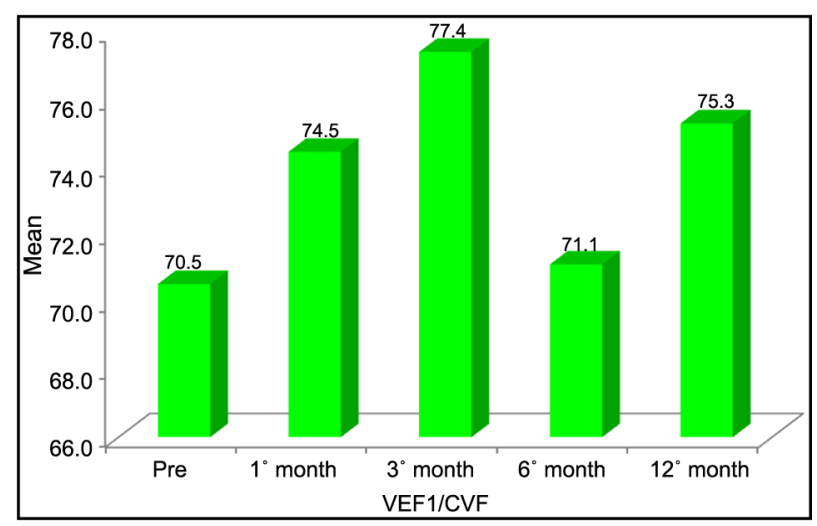

Figure 5. Mean values of FEV1/FVC of four stages: preand postoperatively. There was nostatistically significant differences $(p>0.05)$ when pre- and post-operative values were compared. 


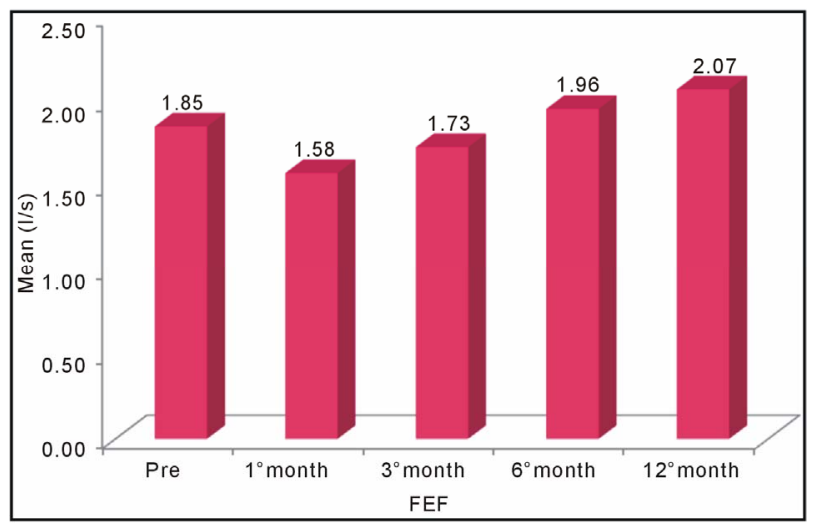

Figure 6. Mean values of FEF four periods: pre- and postoperative. There was nostatistically significant difference (p $>0.05$ ) among all comparisons with the initial FEF.

\section{Discussion}

Spirometry entails performing measurements of pulmonary flow and volumes obtained during the movements of forced inspiration and expiration which are interpreted by a device that transforms these into numbers and graphs.

The technique is indispensable in patients to be submitted to surgical resection, particularly lung operations, because the measurements can help predict the risk of postoperative complications.

In the present study, spirometry was chosen because it is the method most commonly used in surgical practice, is available under our service, and also because the other known methods were difficult to obtain.

The election of tuberculosis as the focus for this study was due to the high incidence of TB patients in the state of Maranhão, the large number of symptomatic sequelae associated with the disease seen at the pulmonology and thoracic surgery outpatient units, and given the fact that these patients are uniform.

Lobectomy was selected as a variable of interest since this allowed comparison of the patient against themselves, after removal of the compromised lobe from the lung.

The curve of normality adopted in this study was that devised by Pereira in 2001 [21], the author responsible for the study of the Brazilian population.

FVC is considered the most important measurement of spirometry because it reflects the maximum limit of flow of expired air after a single maximal inspiration, performed in the shortest possible time.

Any process changing the pulmonary dynamic also affects the maximum flow, representing the most sensitive measurement to variations. In restrictive ventilatory defects, FVC values lie below reference values.

FEV1 corresponds to expirated volume within the first second of FVC, and constitutes the spirometry mea- surement most representative of clinical alterations and restrictive ventilatory defects, and may be normal or reduced.

In the study by Perin [19], he compared spirometric assessments of individuals submitted to abdominal dermolipectomy during the immediate pre-operative period and post-operative period of 19 to 36 months and these values showed no significant difference with correction of rectus musclesof the abdomen.

In the present study, a marked reduction in respiratory function was evident in the first month postoperatively, attributed to the great difficulty of the patient to execute the maneuvers as a result of trauma of the musculature of the chest wall and of pain associated with respiratory force.

Júnior [22], assessing respiratory function in individuals submitted to abdominoplasty, at the preoperative stage and the fourth day postoperatively, observed a decline in respiratory function on the fourth day postoperatively with normalization by the $30^{\text {th }}$ postoperative day.

According to Tercan et al. [23], VC improves significantly up to the 30th postoperative day in abdominoplasty, despite failing to return to pre-operative levels.

In the present study, the improvement in respiratory function was observed as of the $3^{\text {rd }}$ postoperative month as a result of the absence of pain and improved lung compliance, with progressive recovery of the parameters at the $6^{\text {th }}$ postoperative month.

The present study sought to assess whether full recovery of spirometric parameters occurs within a 180-daypostoperative period after lobectomies.

The results obtained showed no significant recovery in spirometric parameters, that did not reached the mean preoperative values 12 months after lung resection. This finding occurred only for FEV1, FVC and PEF measurements.

The authors suggest that studies of lung volumes be performed in order to verify whether the findings can be explained by the reduced lung volumes as a result of lobectomy.

\section{Conclusion}

Based on the results of the present study, it can be concluded that, at the $12^{\text {th }}$ postoperative month, spirometric parameters of patients with tuberculosis sequelae who underwent lobectomy had returned to preoperative levels.

\section{REFERENCES}

[1] C. A. Campos, E. Marchiore and R. Rodrigues, “Tuberculose Pulmonar: Achados na Tomografia Computadorizada de Alta Resolução do Tórax em Pacientes com 
Doença em Atividades Comprovada Bacteriologicamente," Jornal de Pneumologia, Vol. 28, No. 2, 2002, pp. 23-29. doi:10.1590/S0102-35862002000100006

[2] J. N. Muniz, A. Ruffino-Netto, M. Yamamura, T. C. S. Villa, R. Arcencio and R. I. Cardozo-Gonzales, “Aspectos Epidemiológicos da Co-Infecção Tuberculose e Vírus da Imunodeficiência Humana em Ribeirão Preto (SP), de 1998 a 2003,” Jornal Brasileiro de Pneumologia, Vol. 32, No. 6, 2006, pp. 529-534. doi:10.1590/S1806-37132006000600010

[3] S. Bombarda, C. M. Figueiredo, M. B. G. Funari, J. Soares Jr., M. Seiscento and M. Terra, "Imagem em Tuberculose pulmonar," Jornal Brasileiro de Pneumologia, Vol. 27, No. 6, 2001, pp. 329-340.

[4] A. S. Ribeiro, "Tratamento Compulsório da Tuberculose: Avanço ou Retrocesso?” Jornal Brasileiro de Pneumologia, Vol. 29, No. 1, 2003, pp. 50-52.

[5] M. P. T. Silveira, R. F. R. Adorno and T. Fontana, "Perfil dos Pacientes com Tuberculose e Avaliação do Programa Nacional de Controle da Tuberculose em Bagé (RS)," Jornal Brasileiro de Pneumologia, Vol. 33, No. 2, 2007, pp. 199-205. doi:10.1590/S1806-37132007000200015

[6] A. Ruffino-Netto, "Ttuberculose: A Calamidade Negligenciada," Revista da Sociedade Brasileira de Medicina Tropical, Vol. 35, No. 1, 2002, pp. 51-58. doi:10.1590/S0037-86822002000100010

[7] Z. R. Cavalcanti, M. F. P. M. Albuquerque, A. R. L. Campello, R. Ximenes, U. Montarroyos and M. K. A. Verçosa, "Característica da Tuberculose em Idosos no Recife (PE): Contribuição Para o Programa de Controle,” Jornal Brasileiro de Pneumologia, Vol. 32, No. 6, 2006, pp. 535543. doi:10.1590/S1806-37132006000600011

[8] Brasil, "Ministério da Saúde. Tuberculose no Brasil: Avanços e Perspectivas. Programa Nacional de Controle da Tuberculose,” 2010.

http://www.sam.pmrp.com.br/ssaude/programas/tubercul ose/tuberculose_no_brasil.pdf

[9] A. Castelo Filho, A. L. Kritski, A. W. Barreto, A. C. M. Lemos, A. Ruffino Netto, C. A. Guimarães, et al., "II Consenso Brasileiro de Tuberculose. Diretrizes Brasileiras para Tuberculose 2004,” Jornal Brasileiro de Pneumologia, Vol. 30, Suppl. 1, 2004, pp. S2-S56.

[10] T. M. Fernandes, "Sol e Trevas: Histórias Sociais da TuBerculose Brasileira,” História, Ciências, Saúde-Manguinhos, Vol. 11, No. 3, 2004, pp. 767-771. doi:10.1590/S0104-59702004000300012

[11] J. F. Murray, “A Century of Tuberculosis,” American Journal of Respiratory and Critical Care Medicine, Vol. 169, No. 11, 2004, pp. 1181-1186. doi:10.1164/rccm.200402-140OE

[12] C. E. Gazetta, S. H. F. Vendramini, A. Ruffino-Netto, M. R. C. Oliveira and T. C. S. Villa, "Estudo Descritivo Sobre a Implantação da Estratégia de Tratamento de Curta Duração Diretamente Observado no Controle da Tuber- culose em São José do Rio Preto e Seus Impactos (1998-2003),” Jornal de Pneumologia, Vol. 33, No. 2, 2007, pp. 192-198.

doi:10.1590/S1806-37132007000200014

[13] A. Gomes Neto, M. L. Medeiros and J. M. M. Gifoni, "Bronquiectasia Localizada e Multissegmentar: Perfil Clínico Epidemiológico e Resultado do Tratamento Cirúrgico de 67 Casos,” Jornal de Pneumologia, Vol. 27, No. 1, 2001, pp. 1-6. doi:10.1590/S0102-35862001000100002

[14] M. S. Guerra, J. A. Miranda, F. Leal and L. Vouga, "Tratamento Cirúrgico Das Bronquiectasias,” Revista Portuguesa de Pneumologia, Vol. 13, No. 5, 2007, pp. 691701.

[15] K. Balkanli, O. Genç, M. Dakak, S. Gurkök, A. Gözubuyuk, H. Çaylakat, et al., "Surgical Management of Bronchiectasis: Analysis and Short-Term Results in 238 Patients," European Journal Cardiothoracic Surgery, Vol. 24, No. 5, 2003, pp. 699-702. doi:10.1016/S1010-7940(03)00497-4

[16] R. Saad Jr., T. Garrido, R. Stirbulov and F. Rafal, “Avaliação da Função Respiratória de Doentes Submetidos à Operação Abdominal Alta,” Rev. Col. Bras. Cir., Vol. 21, No. 6, 1994, pp. 329-332.

[17] A. M. R. Pinto, "Estudo Comparativo da Função Pulmonar em Pacientes Pós-Revascularizados do Miocárdio, com CEC e sem CEC, com uso de Derivação Intraluminal. Tese [Doutorado],” Faculdade de Ciências Médicas da Santa Casa de Misericórdia de São Paulo, São Paulo, 1999.

[18] A. Helene Jr., “Avaliação da Função Respiratória em InDivíduos Submetidos à Abdominoplastia. Tese [Doutorado],” Faculdade de Ciências Médicas da Santa Casa de Misericórdia de São Paulo, São Paulo, 2005.

[19] L. F. Perin, “Avaliação Espirométrica de Indivíduos Submetidos à Dermolipectomia Abdominal. Tese [Mestrado],” Faculdade de Ciências Médicas Santa Casa de Misericórdia de São Paulo, São Paulo, 2007.

[20] American Thoracic Society, "Standardization of Spirometry, 1994 Update. American Thoracic Society,” American Journal of Respiratory and Critical Care Medicine, Vol. 152, No. 3, 1995, pp. 1107-1136. doi:10.1164/ajrccm.152.3.7663792

[21] C. A. C. Pereira, “Testes de Função Pulmonar. Projeto Diretrizes. Associação Médica Brasileira e Conselho Federal de Medicina,” 2001.

http://www.projetodiretrizes.org.br/projeto_diretrizes/090.pdf

[22] A. Helene Jr., “Avaliação da Função Respiratória em Indivíduos Submetidos à Abdominoplastia. Tese [Doutorado]," Faculdade de Ciências Médicas da Santa Casa de Misericórdia de São Paulo, São Paulo, 2005.

[23] M. Tercan, M. Bekerecioglu, O. Dikensoy, H. Kocoglu, B. Atik, D. Isik, et al., "Effects of Abdominoplasty on Respiratory Functions: A Prospective Study,” Annals of Plastic Surgery, Vol. 49, No. 6, 2002, pp. 617-620. doi:10.1097/00000637-200212000-00011 